Iran

Journal of the British Institute of Persian Studies

ISSN: 0578-6967 (Print) 2396-9202 (Online) Journal homepage: http://www.tandfonline.com/loi/rirn20

\title{
The Curious Case of the Nuclear Company of Britain and Iran
}

\section{Ali M. Ansari}

To cite this article: Ali M. Ansari (2017): The Curious Case of the Nuclear Company of Britain and Iran, Iran

To link to this article: http://dx.doi.org/10.1080/05786967.2016.1277098

册 Published online: 07 Apr 2017.

Submit your article to this journal \lceil

Џ Article views: 6

Q View related articles $\square$

View Crossmark data ¿ 


\section{The Curious Case of the Nuclear Company of Britain and Iran}

\begin{abstract}
Ali M. Ansari
School of History, University of St Andrews, St Andrews, UK

ABSTRACT

In February 1977, on a routine visit to Tehran, Sir Walter Marshall, the chief scientist at the department of Energy and deputy chairman of the UK Atomic Energy Authority, was made a seemingly impromptu "radical proposal" by the then head of the Atomic Energy Organisation, Dr Akbar Etemad for a strategic collaboration between the emergent nuclear industry of Iran and that of the UK which faced an uncertain future. Etemad's proposal envisioned Iranian capital combining with British expertise in the form of a joint company that would be the salvation of both and mark a definitive new era in British-Iranian relations. Eighteen months of tough negotiations ended, failing to yield the desired commitment. But the encounter, largely ignored by historians sheds important new light on the politics of development in both Iran and the UK, along with the complexities of policy-making, and not least, the subtleties of the British-Iranian relationship in what would turn out to be the twilight of the Pahlavi dynasty.
\end{abstract}

KEYWORDS

British-Iranian relations; nuclear industry; development; Akbar Etemad; Walter Marshall; the Shah

\section{A radical proposal}

In early February 1977, Sir Walter Marshall, chief scientist at the department of Energy and deputy chairman of the UK Atomic Energy Authority, arrived in Tehran for what was assumed to be a routine meeting with the President of the Atomic Energy Organisation of Iran (AEOI), Dr Akbar Etemad. Britain had been a key player in the supply of services and training to the emerging Iranian nuclear programme and the visit had been arranged to discuss matters of mutual interest including progress on current contracts and a general review of Iran's strategy in light of more recent US anxieties about nuclear proliferation. Etemad began the meeting by reviewing Iran's programme and reassuring his British interlocutors that while Iran was keen on ensuring technology transfer sufficient to enable Iran to reach its ambitious targets, Iran was not seeking "to build enrichment or reprocessing plants ... in the short to medium term".

There then followed a discussion about the possibility of building a training reactor in Isfahan - to which Marshall noted he now had the authorisation from the Secretary of State to proceed - before, after some deliberation about the state of the British nuclear industry, Etemad turned to Marshall and, "said that he would like to make a radical proposal ... on a personal basis".

As he saw it, the UK were [sic] on the brink of a series of crucial and linked decisions, on thermal reactor type, on the role for NPC, on the future of the boiler making industry and on the future of the turbine industry. Furthermore because of competition from North Sea oil and gas this entire industry was to be heavily export orientated. Simultaneously Iran had become dissatisfied with its lack of participation in the German and French nuclear industries despite the large contracts Iran had placed with them. Therefore, provided the UK chose the PWR for its own programme, would we consider favourably the idea of Iranian investment in the UK industry so as to equip it properly to supply PWRs for both the UK and Iran markets? ${ }^{1}$

It would be fair to say that the proposal took the British delegation by surprise. It envisaged the establishment of a joint nuclear company, combining Iranian capital with British technical expertise, to energise and oversee the development of the nuclear industries in both Britain and Iran. Indeed, the idea was quite revolutionary in its conception and ambition. In effect, it sought to bind the British and Iranian economies in a strategic alliance that would see massive Iranian capital investment in Britain's declining industrial base, in return for the eventual transfer of key technologies. Etemad had effectively thrown the British nuclear industry a lifeline in a fully collaborative venture that would enhance, by stages, the industrial and technical base of both countries. Unsurprisingly, for all the enthusiasm of Marshall and his colleagues, the broader political and diplomatic establishment remained sceptical. For some months thereafter, British officials debated the merits 
of the offer and whether it was genuine, or as the British Ambassador Antony Parsons noted as late as July 1977, whether Britain was being used "Judas goats to bring on other potential, but reluctant partners". ${ }^{2}$ Parsons, along with other key players, eventually concluded that the offer was too good to pass up and that it deserved serious attention resulting in extended discussions towards the formation of a detailed, Outline Plan, for the formation of the company.

That matters never ultimately proceeded had as much to do with economic decisions in Britain as it did with anxieties over long-term political stability in Iran or indeed concerns over proliferation. Indeed, the initial enthusiasm with which British and Iranian officials approached the prospective arrangement belies the popular perception of a political relationship hampered by persistent and deleterious suspicions. On the contrary, quite apart from the structural reasons for collaboration, the evidence suggests a relationship bound by personal mutual respect. Indeed, the secrecy that pervaded the talks had as much to do with precluding the damaging intervention of competitors as with anxieties over domestic repercussions. ${ }^{3}$ But this episode also sheds important light on industrial and political policy, as well as the nature of policy-making, in both Britain and Iran, during a decade in which nuclear energy was still regarded as the solution to mankind's expanding energy requirements. This was in effect the high water mark of the nuclear industry and Iran had the means and the determination to join this exclusive club: not simply for the economic benefits it might bestow but perhaps as its shrewd officials recognised, for the political bounties it might confer.

\section{Preamble}

Iran's interest in nuclear energy can be traced back to President Eisenhower's “Atom's for Peace” policy in 1957. Little substantive progress was made beyond this and the modest research reactor established in the University of Tehran was shut down in 1969 due to a "lack of technically qualified operating staff and the absence of a planned research programme". Indeed, by the end of that decade, Iran's modest foray into nuclear physics had effectively stuttered to a halt. Perhaps the most significant development for the future was its early adoption of the Nuclear Non-Proliferation Treaty
(NPT) in 1970, to which it was one of the first signatories. As Iran entered the 1970s, there was little indication of any further developments though as an intriguing encounter in 1972 indicated, the Shah - now comfortably settled on his throne - remained interested. On a state visit to the UK in 1972, the Shah had a discrete meeting with Lord Victor Rothschild, then head of Prime Minister Edward Heath's Central Policy Review Unit. Rothschild,

raised the question of nuclear power with the Shah. He said he was interested in keeping technologically abreast of the United States and Great Britain. I explained to him there was the possibility of his being ahead of these two countries in the Breeder Reactor Field. ${ }^{5}$

It should come as no surprise that the Shah was interested but it would be another couple of years before there was any substantive movement and despite the initial profession of interest, Britain enjoyed more of a supporting role as the plans for the Atomic Energy Organisation of Iran began to take shape. The turning point came in 1974. At the end of the previous year, the Shah had announced the quadrupling of oil prices at a press conference in Niavaran Palace - an oil price shock that came fast on the heels of an earlier hike in prices following the Yom Kippur War. ${ }^{6}$ Iran's economy was suddenly flush with money on a scale few could have imagined. Almost overnight, the Shah was transformed in the public imagination from the "enlightened" autocrat of a sympathetic third world power, to the "Emperor of Oil". Threats and opportunities abounded but above all the Shah and his thoroughly "modern" Iran had to be acknowledged and respected rather than tolerated and accommodated. Indeed, Iran's newfound status and the responsibilities it now aspired to demanded a whole new vision for the future which could not only be imagined but through the bounties of oil money, realised. There was a keen sense that for all past difficulties, this was Iran's moment, and it had to be seized. No one had a more acute sense of urgency than the Shah himself. The experience of the Indo-Pakistan war of 1971 had convinced the Shah that Western security guarantees were rarely cast iron: a sense of vulnerability that was only enhanced by India's detonation of a nuclear device in May 1974. For the West, the opportunities afforded by Iran's nuclear ambitions were likewise qualified by anxieties over proliferation now heightened by developments in India (India had developed the technology from civil nuclear components delivered by Canada), resulting

\footnotetext{
${ }^{2}$ AB 48/1531, "Letter from Sir Antony Parsons to Edward Burrows."

${ }^{3}$ Indeed, Lord Weinstock, the Chairman of GEC was kept in the dark till late May 1977, prompting a robust letter to the Prime Minister, PREM 16/1418, "Letter from Weinstock to Prime Minister Callaghan."

${ }^{4} A B$ 48/1286, "Visit to Iran from 13th to 19th December 1975."

${ }^{5}$ PREM 15/1684, "Meeting, Shah-Rothschild."

${ }^{6}$ BBC SWB ME/4485/D/1, "Shah's Press Conference."
} 
in the formation of the Nuclear Suppliers Group - The Club of London - in $1975 .^{7}$

Meanwhile in March 1974, the AEOI was established under the presidency of Dr Akbar Etemad, ${ }^{8}$ the then chancellor of $\mathrm{Bu}$ Ali Sina University in Hamedan, a new university which he had been instrumental in founding, and which by all accounts he was quite reluctant to leave. However, the Shah was quite determined to have him in post and after some reflection, he decided to take on the challenge on the basis that he would have at least one month to conduct a feasibility study of what needed to be done and more importantly, that he would answer directly to the Shah. With these points agreed, Etemad proceeded to sit with the Shah's chief of staff, Nosratollah Moinian, and draft the farman for the Shah's signature. ' The challenge was vast not least because of the Shah's ambitious targets and the absence of any serious infrastructure in terms of personnel and material. ${ }^{10}$ The Shah had set a target of 24,000 MW of electrical energy to be supplied by up to 20 nuclear power plants by 1994, when it was imagined Iran's oil resources would be in serious decline. ${ }^{11}$ Iran's total energy requirements by 1994 had been estimated at 70,000 MW with the balance being provided by, gas, hydroelectric and even solar power, but perhaps what is most remarkable about these figures was the fact that Etemad himself was never quite clear how they had been reached and why for example, a third had been allocated to nuclear generation. ${ }^{12}$ These targets appeared quite arbitrary and according the Etemad were regarded as more aspirational than practical. ${ }^{13}$ Etemad has subsequently speculated that they may have resulted from a public imperial pronouncement that could not be subsequently withdrawn. ${ }^{14}$

In other respects, however, there appeared to be considerable synergy and agreement between Etemad and the Shah as to the direction and nature of nuclear policy. Moreover, contrary to the popular view, ideas and strategy regularly originated with Etemad to be later confirmed by the Shah and the President of the AEOI was not afraid to contradict his master, who, according to Etemad, was not averse to being challenged, if he felt a good case could be made. Indeed, Etemad's relationship with the Shah reflected his own approach and policy towards the talent that he drew to the AEOI, most obviously Ahmad Sotoudeh Nia (Project Manager for Nuclear Power Plants), whom Etemad later singled out for particular praise. ${ }^{15}$ Indeed, the impression that is regularly presented, of a highly centralised political and managerial structure in late Pahlavi Iran - a view it must be said that was held by the British - is not reflected in Etemad's account of his operations. For Etemad, the failures of Pahlavi government were as much the responsibility of ill-conceived deference, as it was the Shah's apparent proclivity to centralise power in his own hands.

Be that as it may, there was little disagreement on the value of the nuclear industry for Iran, which both viewed as political as much as economic. The nuclear industry was a strategic asset in every sense of the term and this important distinction in the Iranian approach is crucial for understanding why they finally turned to Britain. That Iran had energy needs for expanding industrial and domestic consumption was not in question. The Shah was above all concerned that Iran would run out of sufficient oil reserves by the mid-1990s and that she would require adequate alternative sources of energy to maintain industrial momentum. Energy self-sufficiency was the ambition of many countries in this period and Iran was no exception in regarding nuclear energy as the route. Given the timeframe for the construction of reactors, it was vital that Iran began planning now and by fortunate happenstance, she had the money to do it. But simply energy self-sufficiency was not enough and Etemad in particular was adamant that Iran acquired an industry that had mastered the technical aspects of the trade. Iran had to be technically self-sufficient as well as energy self-sufficient and it had to find a partner that would develop with it. The industry had to have strategic depth so that it would not, as with the oil industry, remain indebted to Western technical expertise. ${ }^{16}$

But beyond this, there was an appreciation that the broader economic benefits of the industry ran parallel to a number of long-term political objectives, not least the ability to provide energy stability for a country that had been subject to the volatility of oil prices and the political consequences that followed. But in tandem with these benefits was the belief that Iran's standing in the international community had been enhanced by its role

\footnotetext{
${ }^{7}$ On the impact of India's detonation, see Etemad, "Interview for Program of Oral History."

${ }^{8} \mathrm{AB} 48 / 1286$, "Visit to Iran from 13th to 19th December 1975."

${ }^{9}$ Etemad, "Interview for Program of Oral History," 86.

${ }^{10}$ lbid., 87.

${ }^{11} \mathrm{AB} 48 / 1286$, "Nuclear collaboration with Iran."

${ }^{12}$ Etemad, "Interview for Program of Oral History," 89.

${ }^{13}$ Ibid., 90.

${ }^{14}$ Akbar Etemad, Interview with Author, London, 25 August 2014.

${ }^{15}$ Etemad, "Interview for Program of Oral History," 133-4.

${ }^{16} \mathrm{Ibid}$., 94. Etemad makes it clear that while Iran may yet be dependent on supplies of uranium (despite two mines subsequently being discovered in Iran, the quality of the uranium matters), the point was technical mastery. See also Hamblin, p. 25.
} 
as an oil power and that this favourable situation would only last as long as oil existed. Consequently, it was felt that with oil expected to decline rapidly from the 1990s, Iran would need something else to continue exercising the leverage - and respect - it currently enjoyed. But if both men appreciated the political dimensions of the nuclear industry, they differed in one significant respect; and that was with respect to the long-term political stability of the country. Indeed, the paradox in this pursuit of energy and hence political security was that the Shah's acute anxieties about future stability encouraged him to set targets that Etemad among others, felt were unnecessary, unreasonable and in fact counter-productive to both industrial and political stability. ${ }^{17}$

The importance of this different approach for nuclear strategy was this: in order to achieve the sort of nuclear energy within the 20-year time frame envisaged by the Shah, a major part of the strategy would by necessity involve "turnkey" contracts, by which Iran would purchase reactors, in their entirety from suppliers with little input into components, or indeed in the management of the reactors, which would be serviced by personnel provided by the supplier. This was undoubtedly the quicker route, but, for Etemad and his colleagues, it was strategically shortsighted insofar as it would not assist in the development of an indigenous (civil) capability. Far better to enter into an agreement with a partner willing to collaborate and share technology than to move quicker but have no access to the scientific base.

Be that as it may, within months of the establishment of the AEOI, and soon after the Indian detonation, the Shah had visited Paris and signed an agreement for technological cooperation with France which entailed the French supply of five nuclear power plants generating some 5000 MW of electricity by the 1980s. In November of the same year, a letter of intent was signed with Framatome for the construction of two plants (900 MW each) to come on stream in 1982 and 1983, respectively, while a further agreement was signed with the German firm, Kraftwerk Union (KWU) for "the supply of a further two nuclear reactors (total $1200 \mathrm{MW}$ ) to come on stream in 1980 and 1981". ${ }^{18}$ There had been some delay in starting the construction due to the inability to find suitable sites, but there was little doubt that Iran had hit the floor running and the trade press was particularly impressed with the Iranian government's decision to take a $10 \%$ stake in the Eurodif enrichment plant then being built in southern France.

In January 1975 Iran agreed to provide a \$1000 m loan to France to alleviate financial problems, and as a part of the deal it won a large stake in France's two massive uranium enrichment plant projects... This was a smart move to secure safe supplies of enriched uranium fuel. ${ }^{19}$

At this stage, it appeared that the French were willing to collaborate on technical fronts despite the apparent opposition of the United States and the increasing anxiety which had resulted from developments in India. Yet, despite some US discomfort, it was clear that they too were seeking a share of this emerging market.

The only players not being actively considered were the British. This was in large part due to the state of the nuclear industry in Britain and the decision to pursue Steam Generated Heavy Water Reactors (SGHWR) technology that the Iranians were not particularly interested in pursuing themselves having expressed a desire to develop Pressurised Water Reactors (PWRs). ${ }^{20}$ Lord Aldington, Chairman of the National Nuclear Corporation had visited Iran in December 1974 and had informed the Shah that Britain would not be able to supply SGHWR reactors for some years but would nonetheless like to keep informed of developments should opportunities arise. ${ }^{21}$ British involvement as noted above, remained in the areas of training at Harwell (along with the broader Higher Education Institution facilities) and in service contracts but in a bid to develop contacts, Dr Walter Marshall - Chief Scientist at the Department of Energy - was dispatched in February 1975 as part of a "dialogue" the Foreign and Commonwealth Office (FCO) was trying to establish on technical matters in the wider Persian Gulf area. This proved a shrewd move inasmuch as Marshall was able to establish "a close rapport with Dr Etemad and has had regular discussions with him ...".22

What changed throughout 1975 was a growing frustration with the failure of suppliers to deliver and in many cases, letters of intent were not being converted into contracts. Etemad had expressed himself unwilling to work with either the Americans or the Soviet Union in part because he felt Iran would have little leverage with either of the superpowers and should they choose to drag their feet in the implementation of their

\footnotetext{
${ }^{17}$ Ibid., 103.

${ }^{18} A B 48 / 1286$, "Visit to Iran from 13th to 19th December 1975."

${ }^{19} \mathrm{AB} 48 / 1289$, Middle East Monitor, 32. The article also outlines some quite extraordinary figures for the cost of the programme with direct and indirect costs reaching some $\$ 120$ bn though to 1992. Etemad did not think that these reflected the actual costs, Interview with Author, London, 25 August 2014.

${ }^{20}$ Etemad, "Interview for Program of Oral History," 109.

${ }^{21}$ According to one report, the SGHWRs would not be ready for export till the mid-1980s, see FCO 96/585, "UK/Iran Nuclear Cooperation at Present and the Future."

${ }^{22}$ Ibid. For further detail on the discussions in 1975 see Hamblin, pp. 29-30.
} 
contractual obligations - or indeed in actually getting to a contract in the case of the United States, ${ }^{23}$ there was little Iran might be able to do to bring pressure to bear. Etemad later recounted a chance meeting with a Brazilian colleague in Paris where the latter lamented the protracted nature of the work being conducted by Westinghouse which had been due for last seven years (the work had begun in 1976) and would now be lucky if it was completed by $1989 !^{24}$ Etemad also regarded the Americans as far too transparent in their negotiations, since almost everything had to be aired through Congressional hearings ${ }^{25}$ and the Americans were determined to have additional bilateral safeguard agreements in place before any work could begin. Etemad considered this excessive in light of the NPT, and for good measure, the French considered the American approach, foolish. ${ }^{26}$

As for the Soviet Union, a belated attempt to cultivate links by inviting Etemad and his team to visit reactor sites in the USSR had ended in farce. The 10-day visit in July 1977 had, according to Etemad, "been hell. The team had seen nothing but nuclear installations, many of which would not satisfy any international safety requirements ...". Etemad added that the team had been quite exhausted by the excessive travel but "had been able to confirm for themselves that stories of the Russians cornering supplies of the best Caspian caviar were nonsense. They had been treated to the most appalling stuff!" Regarding Soviet proposals for cooperation, Sotoudeh Nia, "told me that the team had taken particular delight in issuing a firm 'niet"”. ${ }^{27}$ The other country that received short shrift from Etemad was Canada whose barely disguised attempt to bribe Etemad had resulted in the latter walking out of a meeting and refusing to deal with them. ${ }^{28}$ The Germans and the French proved more subtle in their approach to negotiations though were not beyond offering "sweeteners" or indeed attempting to circumvent the process. $^{29}$ The main problem with the Germans was their apparent refusal to countenance any form of technology transfer or to see Iranian components used in the construction of the reactors. ${ }^{30}$ They were determined to supply everything and this contradicted Etemad's overall strategy to move away from "turnkey" contracts. ${ }^{31}$ Moreover, if the Germans had not insisted on bilateral safeguards before starting work, they grew increasingly insistent on securing one as the work progressed. ${ }^{32}$

France's problems were of a different nature. Their willingness to show flexibility on the nature of the contract extended to their overall approach which sought at times to circumvent Etemad and the AEOI altogether and deal directly with the Shah, an approach that reflected a widespread belief - shared by many including the British - that all power emanated from the Shah as did decisions and initiatives. While the Shah might enjoy the final say and was quite capable of making spontaneous decisions, at least as far as the nuclear industry was concerned, the decision-making process was more "devolved" than in other sectors. On at least one occasion, Etemad intervened to prevent a French delegation from meeting the Shah independently of him, only to inform the Shah afterwards, and to be commended for his timely intervention. ${ }^{33}$

If Etemad enjoyed the full confidence of the Shah, he likewise extended his confidence to his own subordinates, most obviously Sotoudeh Nia, whose hard bargaining with the French was duly noted and commended in British internal reviews.

As we have noticed in other sectors recently, it is often the technocrats actually involved in the purchase and construction of equipment who at the end of the day have the strongest say in how things work out. On this score Dr Sotoudeh Nia's track record is impressive. He incurred the wrath of Mr Najmabadi, the former minister of Industries and Mines, when he intervened at a ministerial meeting with M. d'Ornano a year ago (without instructions to do so) to tell the Frenchman that there would be no deal for French reactors unless there was substantial movement on price. When $\mathrm{Mr}$ Najmabadi told him that it was the Shah's wish that the deal should go through, Dr Sotoudeh Nia said that the Shah had entrusted AEOI with the purchase of nuclear reactors on whatever terms they thought best, and that was how they intended to proceed. According to Dr Sotoudeh Nia, the Shah supported this line fully

\footnotetext{
${ }^{23}$ Ibid.

${ }^{24}$ Etemad, "Interview for Program of Oral History," 125.

${ }^{25}$ Ibid., 117.

${ }^{26}$ FCO 96/585, "Westmacott to Wilmshurst." Dated 24 March 1976.

${ }^{27} \mathrm{FCO} 96 / 738$, "Westmacott to Chancery, Moscow." Etemad later confirmed this account and added for good measure that his luggage had been lost for the entire trip, Interview with Author, London, 25 August 2014.

${ }^{28}$ Etemad, "Interview for Program of Oral History," 132.

${ }^{29}$ Etemad, for example, notes that while the French never sought to bribe officials, they did offer him a Legion d'Honneur, which Etemad politely refused. Interview with Author, London, 25 August 2014. On German negotiations and flexibility on costing, see Etemad, "Interview for Program of Oral History," 132.

${ }^{30}$ This was not limited obviously to the Iranians. They grew especially anxious at the prospect of an agreement with Britain to provide a safety assessment of nuclear facilities that would expose their technology to "foreign competitors", see FCO 96/585, "Note of a meeting with H.E. Dr. Akbar Etemad in London."

${ }^{31} \mathrm{FCO}$ 96/738, "Letter from Wilmshurst", dated 16th February 1977.

${ }^{32}$ FCO 96/585, "Westmacott to Wilmshurst." Dated 24 March 1976.

${ }^{33}$ Interview with Author, London, 25 August 2014. See also Patrikarakos, p. 38.
} 
in subsequent talks with President Giscard, and the net result was an agreed price $32 \%$ lower than Framatome had been holding out for. ${ }^{34}$

Despite this insight, the British clung to the view that little could be done without the Shah's prior agreement but that said, this view was qualified by an appreciation of the importance of cultivating links at all levels and in this respect, Marshall's good relationship with Etemad was to be important. In many ways, Etemad and his officials had a far more constructive and productive relationship with the Shah than their British counterparts enjoyed with their own ministerial superiors.

\section{Forging an agreement}

The radical proposal that would emerge in February 1977 was considerably longer in gestation even if the details would not be fleshed out until subsequent discussions were held. But it was quite clear a year earlier that Iran was becoming frustrated with its Franco-German partners to say nothing of the stalled negotiations with the Americans. The Iranians made increasing overtures to the British to become involved and in one meeting between then Foreign Secretary Jim Callaghan and Prime Minister Hoveyda in Tehran in March 1976, the latter said that he had enjoyed an interesting conversation with the British Secretary of Energy but felt that the British needed to be "more aggressive" in pressing their energy prospects. ${ }^{35}$ The Secretary of Energy in question, Tony Benn, had in fact had an audience with the Shah in January of that year and in light of subsequent developments, the visit was in all probability arranged in order to convince Benn, rather than the Shah, of the merits of possible collaboration.

Indeed, prior to his meeting with the Shah, Benn first met with Etemad who gave a detailed and frank presentation of Iran's programme, its ambitions, requirements and current shortfalls, which lay in manpower and infrastructure, though Etemad assured Benn that progress was being made on all fronts. He inquired as to the possibility of further training contracts and also of the likelihood of securing a contract with British Nuclear Fuels Limited (BNFL) to secure further supplies of enriched uranium to complement that being acquired through Eurodif and Coredif in France. The key, argued Etemad, was to diversify supply. He added for good measure that Iran was in the process of surveying for its own uranium deposits, a prospect that engendered considerable interest in Benn who commented that, "a discovery of substantial quantities of uranium would be almost as valuable to Iran as her substantial oil reserves". Etemad then proceeded onto the sensitive matter of reprocessing technology noting that Iran ultimately wanted to seek "total self-sufficiency" in the nuclear field and that he was anxious about Iran becoming dependent or open to economic blackmail by the nuclear suppliers group.

Dr Etemad was also concerned that more and more restrictions were being placed on the transfer of technology - in some cases against normal commercial practice. Iran was, of course, a firm believer in the NPT and did not wish any more countries to gain access to nuclear weapons. But he wanted Iran's status as a sincere signatory of the Treaty to be recognised.

Benn was gracious but non-committal and noted that there was no question of any relationship being anything but equal. He added for good measure that the pursuit of self-sufficiency was unrealistic, "All the industrialised nations of the West were inter-dependent in the nuclear business and they had all learned to live with it". Etemad responded that it was all well and good for Western industrialised countries to be dependent on each other, but quite another thing "for a Middle Eastern oil producer to be dependent on the West". ${ }^{36}$

The meeting ended at 10:15 after which Benn was taken to his audience with the Shah. Here, it was not so much the detail that mattered but the general bonhomie that ensued and the stated belief that with Britain about to become an oil exporter, there were many shared interests and priorities - a view it should be stressed that was promoted by Benn as much as the Shah. The Shah characteristically talked of "our civilisation", drew reference to "Our boys together in Oman", and the need to stick together. He added for good measure that he had noted with satisfaction, "Prime Minister Wilson's statement that Iran was more socialist than the UK". He then proceeded to outline his overall strategy for rapid industrialisation, noting that oil would fund this for the present but that other streams of revenue needed to be developed and oil and gas itself needed to be conserved and not wasted on generating electricity.

As regards Atomic energy the Shah said that his country had engaged herself in an all out programme in order to save oil and gas - even if Iran did possess more gas than the USSR. It was ridiculous, a sin and crime to use oil and gas for electricity generation when atomic power or solar energy could be substituted.

\footnotetext{
${ }^{34} \mathrm{EG} 8 / 332$, Iran: International Nuclear Cooperation, "Westmacott, Minute of meeting with Sotoudeh Nia."

${ }^{35} \mathrm{FCO} 96 / 585$, "Record of a Meeting between the Foreign." In a classic case of politicians getting beyond themselves, Callaghan and Hoveyda agreed to investigate the possibility of collaboration in nuclear fusion; see in this regard the same file, "Wilmshurst to Alston."

${ }^{36}$ FCO 96/585, "Meeting between the Rt. Hon. Mr Anthony Benn."
} 
Following a discussion about the consortium and its failures to lift enough oil, matters soon turned to the status of Britain's new oilfields in the North Sea which the Shah suggested could be the basis of a transformation of Britain's industrial base, "providing that people did not simply see North Sea oil as a source of money and leave it at that". Benn responded with a confidence that an official in the FCO clearly did not share that Britain not only enjoyed a trained industrial workforce, but there existed "a deep stability" in British society.

Following some further discussion of nuclear power with Benn suggesting that Iran might learn from Britain's mistakes and benefit from her expertise - matters turned to political philosophies, and here perhaps surprisingly, hitherto unseen synergies began to emerge. Benn said that,

he had been very impressed by what was being achieved in Iran and commented on the very high quality of the Ministers and officials he had met. The Shah said that even more important than this was the human approach adopted by Iran. Social justice was the major aim and he intended to remove all possible signs of exploitation.

Benn, clearly impressed, asked the Shah how he had formed his vision for the future of Iran and the White Revolution, and was treated to a summary history of his reign (including a reference to "a madman who came to power", helpfully identified by the note-taker as Mosaddeq), after which, "Mr Benn thanked the Shah for a most interesting accounts of the development of his philosophy", adding for good measure that "perhaps the Shah was being too modest in view of his own contribution ...".37

Little surprise that Etemad considered Benn's visit a great success and in a subsequent conversation with Marshall, he added

that it was even more significant that the Secretary of State's meeting with the Shah had gone well. Etemad told me that before the Secretary of State arrived for his audience with His Majesty, the latter had said to him that he was anxious on principle to build up interaction with the UK on nuclear matters so as to counterbalance the large interaction which Iran has at present with France and Germany. ${ }^{38}$

The political ground suitably prepared, Etemad began to probe the possibilities of collaboration with Marshall, especially the possibility of investing in a joint enterprise on "centrifuge enrichment". This was important because current supplies of enriched uranium were guaranteed only until 1988. Etemad expressed anxiety, however, about the growing restrictions being imposed by the "club of London", and he noted that discussions with the United States had collapsed completely because he had come to the conclusion that they wished to impose arrangements that would actually "penalise signatories to the NPT". Responding to Marshall's request for more clarity, Etemad stated,

If he invests in a joint centrifuge enterprise he wishes to reserve an option - if this makes economical good sense - eventually to build a plant in Iran, jointly with his UK partners. he emphasised that any such plan would be fully covered by IAEA safeguards and he also that there was no policy decision by the government that they wanted to build such a plant but there was a policy decision that they would not enter into any agreement which forbad them to build such a plant.

Etemad, clearly keen to test the mood, added that he would also like to explore the possibility of joint enterprise to reprocess Iranian nuclear fuel in the UK, retaining the option, as Japan had done, to build a reprocessing plant in Iran at some time in the future, "subject to IAEA safeguards". When Marshall noted that he would transmit these views to the relevant people back in the UK and encouraged Etemad to take these matters up in direct negotiations, Etemad responded that, "he would prefer not to do so at the present time but asked me instead to investigate these ideas along the lines outlined and then make proposals to him" (italics added). ${ }^{39}$

The two men next met in London on 9 February following Marshall's discussion with colleagues in the UK government. It was clear to both that any agreement faced significant political obstacles, both domestic and international and that these would need to be addressed. Marshall assured Etemad, much to the latter's satisfaction, that his understanding of the Club of London was that its primary function was to facilitate and enforce "to all practical extent the NPT Agreements and IAEA safeguards". Drawing attention to a proposed French contract for reprocessing plant in South Korea that had fallen through, Etemad raised concerns that this might have resulted from American pressure no doubt due to the inherent instability of South Korea, adding for good measure that he hoped that such tactics would

\footnotetext{
${ }^{37} \mathrm{FCO} 96 / 585$, "Note of the Secretary of State for Energy's Audience," 1-8. This note ends with the following remarkable statement about the Shah's plans for his succession: " ... the Shah said that he planned to hand over to the Crown Prince in thirteen years time. After the conclusion of the current 5-year Plan, he hoped to see through another two and plan a third". There is no other record of the Shah having been so specific with regard to the timetable for succession and Etemad has no recollection of this having been said.

${ }^{38} \mathrm{FCO} 96 / 585$, "Note for the record on a discussion with Dr Etemad," 1.

${ }^{39}$ lbid, 3-4.
} 
not be applied to "stable" countries like Iran. Furthermore, "he was clear that, because Iran had signed the NPT, there was no bar to the UK supplying a reprocessing or enrichment plant to Iran at some time in the future". ${ }^{40}$ This last statement and the contention that Iran was "stable" were both highlighted by one diplomatic reader of this note, reflecting the different perception of Iran's position, to say nothing of the interpretation of the NPT, but also perhaps the impending disagreements that would surface between Britain's nuclear and foreign policy establishments towards the possibilities of such a strategic engagement with Iran.

In Walter Marshall, however, Etemad clearly had a sympathetic ear, even if Marshall was at pains to emphasise the various safeguard agreements that would have to be implemented should Iran decide that it wanted a reprocessing or enrichment plant of its own. Among these safeguards were the physical protection of any site; an assurance that Iran would not re-export technology to a third country without the prior agreement, and an assurance that should an enrichment plant be built, Iran would agree to a cap of $20 \%$ enrichment unless otherwise agreed with the UK. Most grating for Etemad was the insistence that Iran provide further assurance that the technology would not be used to produce an explosive device through the implementation of a bilateral agreement which would likewise cover any further plants built in Iran. Etemad felt that in light of the NPT, this was surplus to requirements, and enquired if the safeguards would still apply if Iran were at some later stage to withdraw from the NPT. Marshall confirmed that such obligations would remain under the terms of the bilateral agreement. Etemad turned the discussion towards the commercial restrictions this would apparently place on Iran on the basis that Iran might in due course develop nuclear technologies of its own. Marshall "agreed that a suitable form of words would have to be agreed since it was not the intent of the UK that Iran should suffer commercial disadvantages from a Government to Government agreement addressed to 'political' matters". There followed some brief discussion on the merits of regional fuel cycle centres being promoted by the United States, but which both parties agreed were impractical and a British admission that given its nuclear agreements with the Germans, French and the Dutch, some level of consultation with her European partners would be required. In sum, Marshall conceded that Britain would not at present be able to facilitate any agreement with Iran entirely on its own.
Matters then turned to the crux of the discussion as Etemad sought to probe further into the possibilities of an equity participation in which the Iranians would first buy a share in a UK plant, send technicians and engineers, followed by a third phase when the UK would take an equity share in an Iranian enrichment plant based on centrifuge rather than diffusion technology. At all stages, Etemad was keen to stress the necessity not to sign any agreements that might put Iran at a technological disadvantage at any time in the future. So, for example, the Iranians were not at all sure they wanted a reprocessing plant at the moment, "but they were sure that they did not want to come to any agreement which forbad it in the future" (emphasis in the original). The discussion ended on the basis that Marshall would go away and prepare a proposal that would facilitate Iran's plans to install reactors at an average rate of $1500 \mathrm{MW}$ per year through the 1980s.

\section{The agreement}

Despite this encouragement from Etemad, the British were slow to move on his suggestions. Part of this no doubt reflected the natural procrastination of bureaucracies and as Hoveida's comments (noted above) in March 1976 indicated, the Iranians were finding British inaction increasingly frustrating if not a little bewildering. For all the progress being made on the agreements with the French and the Germans, both these partners had their own problems for the Iranians and indeed for the all the French enthusiasm, Etemad noted an anxiety that they would ultimately drive a much harder bargain on account of their not having yet signed the NPT. The British reluctance to get engaged in the Iranian nuclear programme, however, also probably reflected the weaknesses of their own industrial strategy which had made them increasingly dependent on the European partners and the fact that internal disagreements persisted as to the merits of such an extensive and strategic economic partnership, pregnant as it was with political consequences. ${ }^{41}$ Nonetheless, by February 1977, Etemad decided to raise the stakes and rather than wait for a proposal from the British, decided to anticipate it with one of his own. ${ }^{42}$ Despite Marshall's belief that such a proposal would have been "inconceivable" without the prior agreement of the Shah, Etemad suggests otherwise. According to Etemad, the precise parameters of the proposal were basically developed by himself, partly it would

\footnotetext{
${ }^{40} \mathrm{FCO} 96 / 585$, "Note of a meeting with H.E. Dr. Akbar Etemad in London."

${ }^{41} \mathrm{FCO} 96 / 585$, "Wilmshurst to Alston."

${ }^{42}$ Quoted above, p. 1
} 
seem to draw the British in - after their frustrating reluctance to take the bait over the previous year - and only if it elicited a favourable response would the Shah have been informed. As Marshall himself noted in his personal thoughts on the meeting,

The proposal offers the entire market and he still plans 23,000 MW at about 2000 MW a year, very roughly $\$ 2,000 \mathrm{~m}$ a year. He is well aware of the advantages to balance of payments and jobs in the UK. He means to be tempting us. ${ }^{43}$

Marshall was clearly struck by the Iranian frustration with both the French and the Germans, who had reportedly been far too greedy in Iranian eyes, and he noted with some satisfaction "that the main asset the UK has is honesty", though this statement did implicitly reflect the reality that the British nuclear industry as it stood was not capable of fulfilling the opportunity that had presented itself.

Wilmshurst noted that the deal was predicated on Britain choosing PWR and even if ministers went down this route, "we would have to buy the technology from abroad, either from the United States, France, or the Federal Republic of Germany", all of which were likely to look askew at selling Britain the means to dominate the Iranian market. ${ }^{44}$ Officials noted in the margins that there were "formidable" arguments against involvement but that the proposal (since in their view it must have had the approval of the Shah) needed to be taken seriously. With customary clarity, the British Ambassador, Sir Antony Parsons, noted that Etemad was proposing nothing less than, "an arrangement whereby Iran would participate financially in the reorganisation of the British nuclear industry". He added that the potential (mutual) gains were enormous. AEOI were clearly disenchanted with the "turnkey principle" which they had pursued in part because of the short timetable presented to them by the Shah. But now they appeared to have more time by which they could develop the industry in a joint venture, "perhaps using an Anglo-Iranian company", that would ultimately yield profits to Iran as well as a measure of technology transfer. ${ }^{45}$ The issue of technology transfer was one that rankled with British officials, not least because of the need to manage expectations but also because of the anticipated reaction of the Americans. Marshall was more sanguine,
Eventually, but in my view not for another ten years at least Etemad will ask for reprocessing and enrichment technology. Given the state of Iranian industry we ought to be able to put him off until near the end of the century. ${ }^{46}$

Such assurances would not convince everyone. Even before Etemad's proposal had been made, anxieties about the consequences of any cooperation were being voiced in the Ministry of Defence (MOD) where one official asked to comment on the possibilities of cooperation outlined in a paper, noted in the opening paragraph,

I cannot help but conclude that the paper is drafted so as to hide the fact that Ministers are being invited to put commercial interests ahead of non-proliferation considerations when it comes to the possibility of providing re-processing and/or enrichment technology. ${ }^{47}$

Westmacott's assessment of the proliferation risk was more nuanced.

Access to technology for either enrichment or reprocessing would give Iran a potential capability to develop nuclear weapons. Iran is party to the NPT and we have no reason to suppose that she intends to develop nuclear weapons, but a future change of policy cannot be ruled out. Iran has no economic need for either an indigenous enrichment or reprocessing plant at present, but could have when her nuclear programme is much further developed. Moreover the importance which the Iranians attach to being able to acquire this technology in the longer term might be sufficient stimulus to initiate domestic $\mathrm{R}$ and $\mathrm{D}$, if potential suppliers were completely to close the door now on eventual technology transfer. Unless such a response by the Iranians can be discounted, the interest of non-proliferation would therefore be better served by not completely ruling out the possibility of eventual transfer of enrichment and/or reprocessing technology. (Italics added) ${ }^{48}$

These reservations aside, Marshall led a team including Ned Franklin back to Iran in the following July, where according to Parsons, "From the start it was clear that the Iranians meant business". At the opening session on 23 July, much to Parson's surprise, Etemad was accompanied by one Cyrus Ansari, the brother of the Minister of Economics and Finance, Hushang Ansari.

Ansari's presence was of considerable significance. Not only does it mean that his brother - a very powerful man - is in on the act, but also as Cyrus is only used by the Shah for major politico-economic negotiations

\footnotetext{
${ }^{43} \mathrm{FCO} 96738$, "Note for the Record of Discussions in Iran." Visiting London also was noted as an attraction for Etemad's staff. Note that the figure of $23,000 \mathrm{MW}$ differs from that recorded in $A B$ 48/1286 cited above.

${ }^{44}$ FCO 96 738, "Note from Wilmshurst."

${ }^{45}$ FCO 96 738, "Parsons to Burroughs."

${ }^{46}$ FCO 96 738, "Note for the Record of Discussions in Iran."

${ }^{47} \mathrm{EG} 8 / 332$, "Letter from MOD to Department of Energy."

${ }^{48} \mathrm{EG} \mathrm{8/332,} \mathrm{"Westmacott} \mathrm{to} \mathrm{Wilmshurst."} \mathrm{Dated} 21$ February 1977.
} 
where the Iranians either mean real business or want to give the impression that they do.

This last caveat was revealing, inasmuch as the shear energy of the Iranian side far from engendering confidence, had quite the opposite effect on Parsons who wondered aloud whether this was all a bit of theatre intended to galvanise Britain's competitors.

... [W] are still not quite sure what the Iranians are up to. Normally negotiations in Iran are very difficult and very slow. Yet here we are with a top level Iranian team making much of the running in the conclusion of a provisional agreement covering an extremely ambitious and complex scheme of cooperation without once appearing to have stopped to consider such basic questions as, for example, the competence of British industry to fulfil the function asked for it. ${ }^{49}$

The meetings which went over "three days of hard negotiations - in some cases up to 15 hours non-stop", resulted in a detailed (eight-page) memorandum which outlined mutual expectations. This envisaged the establishment of a joint company to develop the nuclear industries in both Britain and Iran and was clearly predicated on the development of PWRs. The first such reactors would not be built in Britain till 1980 at the earliest with construction in Iran from 1982/1983. Although it stressed the civil nature of the programme to be developed, it was clear from the memorandum that the acquisition of technology and skills training were vital components of any agreement. Similarly, although due consideration would be made of the respective industrial bases in each country, it was anticipated that components would be made in Iran as well as Britain. Moreover, the memorandum stipulated that, "It is intended that the Company should develop so as to provide full and equal access to technology to the Iranian and UK partners within the Company" ${ }^{50}$ The company would be the only supplier of PWRs to the UK with matching responsibilities in Iran. Where the number of reactors in Iran exceeded the number planned for the UK, while the company would effectively enjoy first refusal on all orders but that this should not detract from the ability of AEOI to place orders with other suppliers if need be. The ownership of the company would be on a 50:50 basis.

Further details would be provided in the "Outline Plan for the Formation and Operations of the Nuclear Company of Britain and Iran (NCBI)", the second draft of which was completed by 8 September. ${ }^{51}$
This specified the objectives of the company, to "design, market, manufacture, construct and commission PWR power stations [...] and related supplies and services in Iran, the UK and third countries", and "to establish the appropriate technological and manufacturing bases in Iran and the UK, acquiring both Iranian and UK staff for that purposes within general principle of symmetry and equality of access to information". The company would be the only suppliers of PWRs in the UK and would supply the equivalent to Iran with any over the UK number being ordered from the company on a preferential, if not exclusive, basis. The initial two orders would begin in the UK in 1980, to be followed by Iran in 1982/ 1983. Following the construction of the initial two power stations in each country, there would be at least one additional power station commissioned every subsequent year. Given the lack of parity between the industrial bases in each country, work would be begin in the UK and gradually transfer to Iran as technological and industrial parity was achieved. Employment in the company and its subsidiary bodies in Iran and the UK would be open to nationals of both countries. Care would be taken to address the technical and cultural differences,

Certain nominated appointment based on nationality can help promote good relations and these are made to ensure that the problems and backgrounds of nationals transferred to the other country are properly understood and that differences between national attitudes and practices do not become sources of friction.

The 19-page plan went into considerable detail as to the practicalities of the collaboration though even here in some cases the implications were implicit rather than explicit, and questions remained over how the work would be shared in the initial stages and indeed whether the British government would choose PWR power stations - a decision on which, as far as the Iranians were concerned, the entire agreement depended. But the mood was one of optimism and at one level, at least the political will seemed to exist. In a follow-up visit to Tehran at the end of September, Lord Aldington stressed, to Etemad and Prime Minister Amouzegar's agreement that, " ... the important aspect of the co-operation was on the ground. The project would only work if we in Britain treated the Iranians involved as British and if the Iranians treated the British involved as Iranians". This was a remarkable statement of intent, and Parson's

\footnotetext{
${ }^{49}$ AB48/1531 UKAEA, "Nuclear collaboration with Iran." In an earlier meeting on 24 July at the AEOI offices in Tehran, Marshall explained that there remained a "credibility gap" in Britain over the likelihood of the collaboration, "Notes of a Meeting at the Offices of the AEOl." Tehran, 24 July 1977, Dated 1 August 1977. ${ }^{50}$ FCO 96/738, "Cooperation between UK and Iran on Nuclear Power Matters." Memorandum, Dated 25 July 1977, article 4.1.3

${ }^{51}$ AB48/1531 UKAEA, "Outline Plan."
} 
noted to his satisfaction that his earlier doubts were dissipating. ${ }^{52}$ The Shah was likewise in buoyant mood. According to Parsons,

The Shah was fully briefed. He was enthusiastic about the prospect of cooperating with us, saying that it seemed particularly appropriate in that his oil and our North Sea Oil would probably run out at roughly the same time i.e. sometime in the 1990 s. $^{53}$

\section{Fallout}

The seriousness of the proposal was underlined by the changing nature of the discussion in Whitehall. Though British officials stressed that nothing had been committed as yet, the momentum was swinging towards the launch of an extraordinary economic and political pact which would have bound Iran and Britain for least a generation. Indeed, it was remarkable that within 25 years of the nationalisation of the Anglo-Iranian Oil Company, both countries were contemplating engaging in a far more intimate - if undoubtedly more balanced joint venture, which in the words of Aldington, would have in practice resulted in British and Iranian nationals being treated as nationals of the other country. There were questions of capacity and capability on both sides, and of course, the agreement remained dependent on a British decision to choose PWR power stations. Similarly, there was considerable anxiety about the potential for dual use technology transfer though Aldington among others felt that this would be better contained through engagement rather than a blanket ban, which would likely provoke and encourage the Iranians to move ahead on research and development. Britain's advantage - ironically given the popular historical view - was not only that it was deemed an honest partner, but also that it took the Iranians seriously. "What Iran wanted was for the UK to treat her seriously as a full partner. The Iranians did not believe that the French or the Germans, for instance, would ever do this". ${ }^{54}$

Given the strategic nature of the proposed collaboration, matters now moved to questions of political stability and public opinion in the UK, especially with regard to the human rights situation in Iran. It was acknowledged that Iran received particularly bad coverage of its human rights record in the Western press, but the sober assessment of the FCO was that the Shah was not the worst offender, and perhaps more intriguingly, "that it was possible that it [human rights] might have now passed its peak as an important issue". This was probably optimistic given the Shah's own apparent lack of awareness about public opinion in the West. In an interview for the Chicago Tribune, the Shah "reaffirmed" that there were only 2200 political prisoners in Iran, an aside that elicited astonishment from the FCO reader. ${ }^{55}$

In a subsequent meeting with the Secretary State for Energy, Tony Benn, Lord Aldington outlined the mutual benefits for the British economy and the interest Iranians had in acquiring expertise. Aldington noted that the idea of a 50/50 partnership harboured some difficulties not least because from the British perspective, the weight of expertise being contributed would, initially at least, be far in excess of anything the Iranians could contribute, so some consideration might be given to lowering Britain's initial financial outlay. At the same time, Britain could expect to earn between $£ 100$ and $£ 180 \mathrm{~m}$ per year in orders for plant and equipment, from 1985 onwards rising to $£ 230 \mathrm{~m}$ per annum by the end of the century. ${ }^{56}$ Questions remained over the wisdom of technology transfer, and the Iranian attitude to human rights; questions that were raised in more detail in a follow-up paper requested by Benn. In the cover letter to the paper, Aldington made clear that much hinged on Britain selecting PWRs for its own nuclear programme, though he added in the paper that the Iranian government would be flexible enough for Britain to select a mix of reactors as long as PWRs were among that mix. Aside from the positive impact that was likely to emerge for broader industrial relations and trade with Iran, Aldington noted the benefits to Britain's balance of payments and concluded in the section on advantages to Britain that,

We estimate that orders for nuclear power stations by Iran at the rate of one power station per annum would provide employment for several tens of thousands of people in Britain when account is taken of all the work involved.

Moving onto the "questions and difficulties", Aldington posited the issue of Iran's economic strength and purchasing power given the assessment that oil revenue would dwindle by the 1990s and also questioned the inherent stability of the Shah's government and whether there was a possibility of anarchy following the Shah (a likelihood that Aldington considered slight). More to the point, "The question must also be asked whether Iran is considered politically, as a suitable partner for Britain in the nuclear power industry". Presently,

\footnotetext{
${ }^{52}$ AB48/1531 UKAEA, "Parson Note on the Visit of Lord Aldington."

${ }^{53} \mathrm{FCO} 96 / 738$, "Parsons Note on Meeting with the Shah on 13th October."

${ }^{54}$ Ibid. "Record of a Meeting Held with Lord Aldington."

${ }^{55}$ Ibid. "Iranian Policy." The astonishment was probably caused by the Shah's blasé admission more than the fact itself which cannot have been a surprise.

${ }^{56}$ EG 8/332, "Note of a Meeting Held in the Office of the Secretary."
} 
concluded Aldington, answering his own question, he foresaw few problems, especially since Iran was a signatory to the NPT and the "Shah's government does appear to respond to western opinion in a reasonable way". More problematic for Aldington was the question of management and he reiterated his point that,

\begin{abstract}
The management team has to be one, and not two, despite the inclusion in it of people from different countries. The Iranians will be treated as if they were British and vice versa, and there have to be no preference given to any one nationality any more than discrimination against any one. Great care will have to be taken in establishing the principles or organisation and getting Iranian agreement to them.
\end{abstract}

Such practical problems as these were, however, not insurmountable and Aldington concluded the paper by voicing his concern that the real danger to the contract lay in British prevarication over the selection of reactor type. $^{57}$

\section{Denouement}

No sooner had these discussions taken place than the first chinks in the potential agreement appeared with the sudden announcement that Iran had signed further agreements with the Germans and were closely investigating the possibility of further reactor purchases from the French and negotiating for a further eight reactors from the United States. Noting that this would total 20 new reactors, Westmacott was swiftly dispatched to see Sotoudeh Nia.

I suggested to Dr Sotoudeh-Nia that, if accurate, this picture did not leave much of a role for the proposed Irano-British joint venture. He told me that, on the record, he should say there was still room for everyone in Iran's nuclear power programme. "Off the record", he said, "I can tell you that if you don't hurry up there will be nothing left for Britain".

It was clear from Sotoudeh Nia's comments that the joint venture discussed for the better part of the year appeared to have slipped down the list of priorities.

I told Dr Sotoudeh-Nia that I had understood it to be important to Iran to become progressively involved in the design, manufacture and construction of nuclear power plants and that if at all possible there were to be no more turnkey contracts. What he had told me suggested that this was not necessarily the case now. Dr Sotoudeh-Nia sighed. He explained how he had forced Kraftwerk Union to use Iranian manufacturers for low technology components at Bushehr. The only result had been delays and unnecessary expense because in all cases the Iranian components had not been good enough. In his view, a choice had to be made; either one wanted power stations on time that worked, or one wanted them late with the possibility of technical defects as well. As far as he was concerned, it had been made clear to him that the nuclear energy programme was of the highest priority; against his own instincts, he had therefore had to give up trying to force Iranian participation on his foreign suppliers, and he would continue to award contracts to produce working power stations on time. ${ }^{58}$

Sotoudeh Nia had effectively revealed that the "grand design" was off, largely it would seem because of the Shah's urgency to get things done. Having moved away, quite sensibly as far as long-term industrial strategy was concerned, from turnkey contracts that would see no meaningful technology transfer to Iran, the reality of domestic manufacturing limitations and imperial impatience had resulted in two years of planning and discussion being shelved. Etemad was more reluctant to give up on the idea than his deputy and suggested to Parsons that the possibility of a deal still existed but that Iran "could not afford to wait forever". ${ }^{99}$ By February, however, any outside opportunity was firmly closed by the British decision not to pursue PWRs. Although Aldington held out hope that given both sides had shifted, there might still be room for a more modest contract, it was left to Marshall to confirm what was by then an open secret. Meeting with Etemad in Tehran in March 1978, the latter stated that in light of recent decisions he considered,

himself released from the moral obligation to keep open that opportunity until the UK had made its policy decisions... I replied that I was unable to disagree with him on this matter and that I thought Lord Aldington would understand why a major opportunity should now be regarded as closed. ${ }^{60}$

By then, of course, though it seems no one had noticed, the starting gun for the Islamic Revolution had been fired. In the next few months, the Pahlavi monarchy would begin to unravel at a speed and intensity that few had anticipated. The very "anarchy" that Aldington had feared, but most had dismissed as a realistic possibility now increasingly looked like a probability and Iran's ambitious nuclear policy was firmly in the sights of Iran's new coalition of revolutionaries who dismissed the programme as a waste of money that should instead be spent on exploiting Iran's vast natural gas reserves. Etemad was in effect disowned by the Shah

\footnotetext{
${ }^{57} E G$ 8/332, "Note for the Secretary of State for Energy."

${ }^{58} \mathrm{EG} \mathrm{8/332,} \mathrm{"Westmacott,} \mathrm{Minute} \mathrm{of} \mathrm{Meeting} \mathrm{with} \mathrm{Sotoudeh} \mathrm{Nia."} \mathrm{It} \mathrm{would} \mathrm{be} \mathrm{a} \mathrm{further} \mathrm{week} \mathrm{before} \mathrm{the} \mathrm{news} \mathrm{was} \mathrm{digested} \mathrm{in} \mathrm{London.}$

${ }^{59} \mathrm{FCO} 8 / 3207$, "Parsons Minute of Meeting with Etemad."

${ }^{60} \mathrm{AB}$ 48/1291, "Meeting with Dr. Etemad on Saturday 11 March 1978."
} 
and was widely attacked by critics of the regime despite his reputation "as an honest and incorruptible civil servant". ${ }^{61}$ At least he was able to escape the worst excesses of the revolution. Sotoudeh Nia was arrested and incarcerated for four years. Despite these vigorous objections, the Revolutionary Government quietly reviewed and restarted the programme in 1984.

\section{Conclusion}

From a distance, it would be easy to dismiss the idea and the negotiations that followed as an episode of little significance and in fact, it barely registers a mention in most of the accounts of Iran's nuclear programme. Yet, the detail provided by the documents gives the historian an insight into the way industrial policy and negotiations were pursued not only in relation to Iran and the Shah's role - more strategic than tactical but even here open to a degree of persuasion not normally admitted to - but also equally of the UK, where differences in approach become apparent between the Foreign Office, the various officials at the UK Atomic Energy Agency, the MOD and last but by no means least, the politicians. Although the AEOI may have operated on somewhat different parameters from other agencies, it is remarkable to what extent Etemad and his officials, most obviously in this case Sotoudeh Nia, were able to shape the debate. By comparing and contrasting the Persian and British sources and their perceptions of each other, one is able to better ascertain the modus operandi of the AEOI, and the latitude enjoyed by officials is attested to in the British documents even if some of the conclusions ultimately drawn (most obviously about the centrality of the Shah to all decision-making) were somewhat wide of the mark. But what is also intriguing from the accounts is the way in which British officials agonised over the reality or otherwise of the deal on offer, and how Britain's position differed from those of her competitors.

Ultimately, that a deal could be broached and was taken seriously had much to do with the development of personal relationships, in this case between Etemad and Marshall. In not seeking to constantly circumvent Etemad, Marshall was able to build a relationship of trust which ultimately gave the British a position of leverage their competitors could only dream of. As it was pointedly noted in the summary of his February 1977 meeting, one of Britain's key assets was trust, a reality that must have compensated for the many deficiencies in industrial capacity. But it is worth perhaps pausing on this thought for a moment and to see this in the light of established narratives of British-Iranian relations. Etemad saw merits in an arrangement with the British because paradoxically their industrial position was weaker than that of their competitors and their political capacity was by extension diminished. It meant that Iran could participate as close to as an equal as it was possible to be given the state of Iran's own industrial capacity: a capacity that given the Shah's urgency would play a major role in shelving the planned cooperation. But there was a clear logic to what Etemad had in mind with a view to building an industrial capacity at a pace that was sustainable for Iran. But the pace proved too slow for what might be termed the industrial fetishism of late Pahlavi Iran - a fetishism one might add that has been hard to dislodge - and the methodical if slow pace of development was somewhat reluctantly replaced by a return to the much less satisfactory "turnkey" contracts.

Yet, perhaps what is most remarkable about this entire agreement was the scale of the vision and the partner of choice. The partnership being explored would have put the Anglo-Iranian Oil Company in the shade. That it was being discussed at all a mere 25 years after the turbulent nationalisation of AIOC reflects the reality that the narrative of distrust which has become such a feature of the historical landscape was never as emphatic or transparent as its proponents would have us believe.

\section{Acknowledgements}

I am grateful to Dr Etemad for reading through an earlier draft of this paper and offering his insights, thoughts and comments. The arguments outlined and any remaining errors are mine alone. I would like to thank the National Archives for permission to use and quote from the documents referred to in the article.

\section{Disclosure statement}

No potential conflict of interest was reported by the author.

\section{Bibliography}

AB - UK Atomic Energy Authority

EG - Department of Energy

FCO - Foreign and Commonwealth Office

PREM - Prime Minister's Office Records

BBC SWB - BBC Summary of World Broadcasts

AB 48/1286, Nuclear Collaboration with Iran, "Visit to Iran from 13th to 19th December 1975." Briefing Document Dated 11 December 1975.

AB 48/1289, Nuclear Collaboration with Iran, Middle East Monitor, March 1977.

\footnotetext{
${ }^{61} \mathrm{AB} 48 / 1293$, "Electrical Review International."
} 
AB 48/1291, Nuclear Collaboration with Iran, "Meeting with Dr. Etemad on Saturday 11 March 1978." Dated 15 March 1978.

AB 48/1293, Nuclear Collaboration with Iran, "Electrical Review International Vol. 203, No. 13, 6th October 1978.”

AB 48/1531, Nuclear Exports to Iran, "Letter from Sir Antony Parsons to Edward Burrows." Dated 27 July 1977.

AB48/1531 UKAEA, "Nuclear Collaboration with Iran." Parsons to Burrows, dated 27 July 1977.

AB48/1531 UKAEA, "Outline Plan." Dated 8 September 1977.

AB48/1531 UKAEA, "Parson Note on the Visit of Lord Aldington.” Dated 26 September 1977.

Akbar Etemad, "Interview for Program of Oral History, Foundation for Iranian Studies." Conducted by Farrokh Ghaffari, Paris, November 1982. Transcript available online at http://fis-iran.org/en/oralhistory.

BBC SWB ME/4485/D/1, "Shah's Press Conference." 23 December 1973, Dated 28 December 1973.

D Patrikarakos, Nuclear Iran: the birth of a nuclear State, (London, I B Tauris) 2012.

EG 8/332: Iran: International Nuclear Cooperation, "Letter from MOD to Department of Energy," 19 January 1977.

EG 8/332, "Westmacott to Wilmshurst." Dated 21 February 1977.

EG 8/332, Iran: International Nuclear Cooperation, "Note of a Meeting Held in the Office of the Secretary of State for Energy." Room 1237 Thames House South, Millbank SW1, at 2 pm on Tuesday, 1 November 1977, to Discuss the Iranian Proposals on PWR's, dated 4 November 1977.

EG 8/332, "Note for the Secretary of State for Energy from Lord Aldington." Dated 8 November.

EG 8/332, Iran: International Nuclear Cooperation, "Westmacott, Minute of Meeting with Sotoudeh Nia." 15 November 1977.

FCO 8/3207, Nuclear Energy in Iran, "Parsons Minute of Meeting with Etemad.” Dated 9 January 1978.

FCO 96/585, "Note of the Secretary of State for Energy's Audience with HIM the Shah at Niavaran Palace." Wednesday 7 January 1976 - 11:30 am, Dated 9 January.

FCO 96/585, "Meeting Between the Rt. Hon. Mr Anthony Benn, Secretary of State for Energy and HE Dr Akbar
Etemad." 9 am Wednesday 7 January, Note Dated 19 January 1976.

FCO 96/585, "Note for the Record on a Discussion with Dr Etemad." Held on the 26 January 1976, Dated 28 January 1976.

FCO 96/585, "Note of a Meeting with H.E. Dr. Akbar Etemad in London.” On 9 February 1976, Dated 21 February 1976. FCO 96/585, "Record of a Meeting Between the Foreign and Commonwealth Secretary and the Prime Minister of Iran." Dated 7 March 1976.

FCO 96/585, UK/Iran Nuclear Cooperation, "Westmacott to Wilmshurst." Dated 24 March 1976.

FCO 96/585, UK/Iran Nuclear Cooperation, "UK/Iran Nuclear Cooperation at Present and the Future: A factual Summary." Dated 29 March 1976.

FCO 96/585, “Wilmshurst to Alston.” Dated 1 April 1976.

FCO 96 738, "Parsons to Burroughs." 8 February 1977.

FCO 96 738, Cooperation Between UK and Iran on Nuclear Power Matters, 1977, "Note for the Record: Discussions with the President of the Atomic Energy Organisation of Iran in Tehran." 5-6 February 1977.

FCO 96/738, "Letter from Wilmshurst.” Dated 16 February 1977.

FCO 96 738, W Marshall, "Note for the Record of Discussions in Iran." 5-6 February, 1977, Dated 8 February 1977.

FCO 96 738, "Note from Wilmshurst." Dated 16 February 1977.

FCO 96/738, Cooperation Between UK and Iran on Nuclear Power Matters, "Westmacott to Chancery, Moscow." Dated 25 July 1977.

FCO 96/738, Cooperation Between UK and Iran on Nuclear Power Matters, "Parsons Note on Meeting with the Shah on 13th October." Dated 16 October 1977.

FCO 96/738, "Iranian Policy.” Dated 15 November 1977.

FCO 96/738, "Record of a Meeting Held with Lord Aldington (Chairman, National Nuclear Corporation) On 17th October in the Foreign Commonwealth Office.” Dated 27 October 1977.

Hamblin, J. D. "The Nuclearization of Iran in the Seventies." Diplomatic History 38, no. 5 (2013): 1114-1135.

PREM 15/1684, “Meeting, Shah-Rothschild." Dated 2 December 1972.

PREM 16/1418, Nuclear Cooperation, "Letter from Weinstock to Prime Minister Callaghan.” Dated 19 May 1977. 